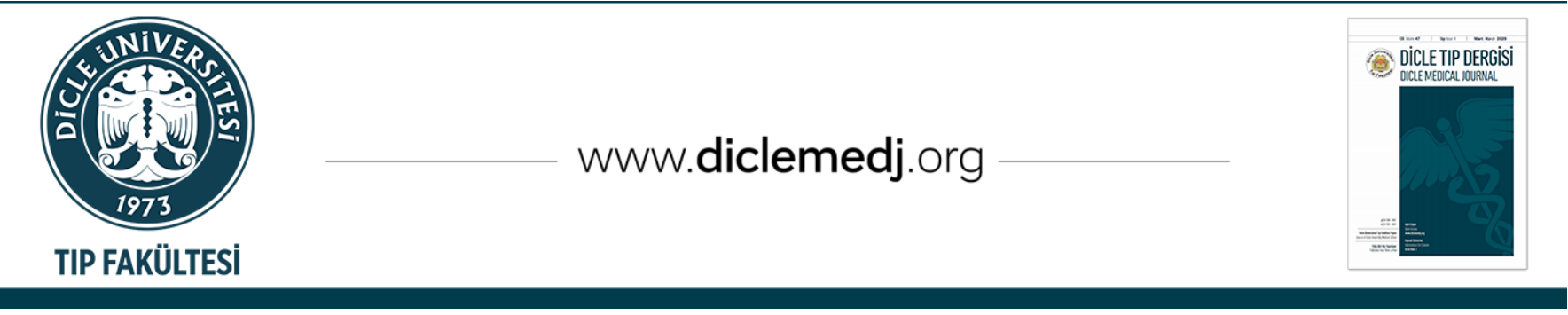

Özgün Araștırma / Original Article

\title{
Mide Kanseri ve Beslenme
}

\author{
Zeki Kemeç ${ }^{1}$, Abdurrahman Işıkdoğan iD 2 \\ 1 Batman Bölge Devlet Hastanesi Nefroloji Kliniği, Batman, Türkiye \\ 2 Dicle Üniversitesi Tıp Fakültesi Medikal Onkoloji Bilim Dal, Diyarbakır, Türkiye
}

Geliş: 04.11.2019; Revizyon: 22.05.2020; Kabul Tarihi: 27.05.2020

Öz

Giriş: Ülkemizde Güneydoğu ve Doğu Anadolu bölgelerinde mide kanseri en sık rastlanan kanserler arasında yer almaktadır. Çalışmalarda beslenmenin mide kanser etyolojisinde önemli bir faktör olduğu tanımlanmıştır. Bu çalışmada, mide kanserinde diyet alışkanlıklarının etkisi araştırıldı.

Yöntemler: Çalışma Dicle Üniversitesi Tıp Fakültesi Hastanesi'nde 2004-2005 tarihleri arasında onkoloji departmanında yürütüldü. Vaka-kontrollü çalıșmada sırasıyla 81 mide kanserli hasta (MCH) , 40 sağlıklı gönüllü birey (Kontrol-1), 40 diğer kanserli hasta (Kontrol-2), 3 ana grup olarak değerlendirildi. Katılımcılara 'Mide Kanseri Takip Formu' (MKTF) ve 'Beslenme Anket Formu' (BAF) kullanılarak anket uygulandı. Bu anketlerde katılımclların demografik ve beslenme özellikleri arasındaki ilişki 'Pearson Chi-Square testi' kullanılarak değerlendirildi.

Bulgu-Sonuç: Üç ana grubun demografik ve beslenme değişkenleri karşılaştırıldı. Farklı sonuçlar bulundu. Bazı değişkenler mide kanseri ile iliş̧iliyken, bazıları ilişkisiz bulundu. İleri yaş, erkek cinsiyet, kırsal yaşam, ev hanımı ve çiftçilik meslekleri, sosyokültürel-sosyoekonomik düzey düşüklüğü, kalabalık ailede yaşam, A kan grubu, sebzemeyveden kısıtlı beslenme, kötü ağız hijyeni ve yetersiz diş firçalama alışkanlığı MCH'larında anlamlı bulundu. MCH'ları et, tuzlanıp-saklanmış et ürünleri, tuzlu peynir, tuzlanmış salamura zeytin, kahve, kırmızı pul biberi, meyve, salata,

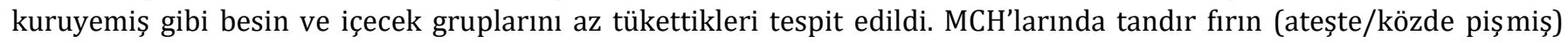
ekmeği ve katı-sıvı yağ tüketimi oldukça anlamlıydı.

Anahtar kelimeler: Mide kanseri, Beslenme özellikleri, Demografik özellikler. 


\title{
Gastric Cancer and Nutrition
}

\begin{abstract}
Objectives: Gastric cancer is one of the most common cancers in Southeast and Eastern Anatolia Regions in our country. Nutrition is an important factor in the etiology of gastric cancer has been identified in different studies. In this study, the effect of dietary habits on gastric cancer was investigated.

Methods: This study was conducted in Dicle University School of Medicine Department of Oncology between 2004 and 2005 . In this case-controlled study, patients were divided into three main groups as followed; Group 1. 81 patients with gastric cancer (GCP), group 2. 40 healthy volunteers (Control-1), group 3. 40 patients with other cancer (Control-2). A questionnaire was applied to the participants by using Gastric Cancer Follow-up Form (GCFF) and Nutrition Questionnaire Form (NQF). In these questionnaires, the relationship between the demographic and nutritional characteristics of the participants was evaluated using the Pearson Chi-Square test.

Finding-Results: Demographic and nutritional variables of three groups were compared. Different results were found. Some variables were associated with gastric cancer, while others were unrelated. Advanced age, male gender, living in rural area, to be housewife, to be farmer, low sociocultural and socioeconomic level, living in crowded families, A blood group, restricted nutrition from vegetables and fruits, poor oral hygiene and insufficient tooth brushing habits were found to be significant in gastric cancer patients. GCPs consumed less food and drink groups such as meat, salted-preserved meat products, salted cheese, salted olives, coffee, red paprika, fruit, salad. In GCP group, tandoor oven (cooked on fire/embers) bread and oil consumption were very significant.
\end{abstract}

Keywords: Gastric cancer, Nutritional characteristics, Demographic characteristics.

\section{GíRIŞ}

Mide karsinomu tüm dünyada sık görülen organ kanserlerinden biridir1. Türkiye'de tüm kanserler içinde mide kanseri erkeklerde ikinci, kadınlarda ise üçüncü sırada yer almaktadır². Beş yıllık yaşam süresi ise \%7-15' dir $^{3}$.

Mide karsinomunun belirli bölgelerde ve belirli toplumlarda anlamlı olarak daha sık olması etyopatogenezinde çevresel faktörlerin araştırılmasına yol açmıştır. Ancak, çeşitli çalışmalarda farklı sonuçların elde edilmesi, araştırmacıları belirli bir besin türünün etkisinden çok besinleri saklama ve pişirme alışkanlıklarındaki farklılıklara ve besinlerdeki koruyucu faktörlerin etkilerine yönlendirmiştir. Özellikle kompleks tahıllardan elde edilen proteinlerin yüksek seviyede, diyette hayvansal yağ ve proteinlerin düşük düzeyde olması, lifli ve taze yeşil bitkilerin seyrek yenilmesi, tuz ve nitratın fazla tüketilmesi mide karsinom gelişimini kolaylaştıran etmenler olarak öngörülmüştür ${ }^{1}$. Japonya da, tuzlu yiyecekler (özellikle balık), sebze turşusu, kurutulmuş balık, balık ızgarası, büyük miktarda pirinç tüketilmesi gibi çeşitli risk faktörleri tanımlanmıştır ${ }^{4}$. Tuz tüketimini azaltan Japonlarda, mide kanseri insidansının azaldığı gösterilmiştir5. Taze, yeşil-sarı sebzeler ve süt koruyucu faktörlerdir6. Buzdolabı dışında yiyeceklerin saklanması için yeni metotların geliştirilmesi, sigara ve tuz kullanımının azaltılması, büyük miktarda taze sebze ve meyve tüketilmesi ile mide kanseri insidansında belirgin bir azalma olmuştur. Mide kanseri ve spesifik gıdaların alımı arasındaki ilişki daha önce yayınlanmış büyük merkezli vaka-kontrol çalışma analizlerinde ortaya çıkmıştır7.

\section{AMAÇ}

Bu çalışma Türkiye'nin mide kanserinde yüksek risk bölgesi olan Güneydoğu Anadolu ve Doğu Anadolu Bölgesi'nden ${ }^{2}$ birçok hastanın başvurduğu Dicle Üniversitesi Onkoloji Kliniği'nde yapıldı. Türkiye'de tipik olarak insanlar tuzlanıp-saklanmış et ve sebzeyi fazla alarak, taze sebze ve meyveyi de sinırlı alarak total kalori ihtiyaçlarını karşılamaktadır. Türkiye'de mide kanserinin yüksek oranda görülmesi böyle geleneksel diyetsel uygulamaların negatif yönde katkıda bulunabileceğini varsaydık. Bu varsayımı test etmek için, tek merkezli vaka-kontrollü kesitsel bir çalışma yürüttük. 


\section{YÖNTEMLER}

$\mathrm{Bu}$ anket çalışmasına 2004-2005 yılları arasında Dicle Üniversitesi Tıp Fakültesi Hastanesinde takip edilen 81'i MCH olan toplam 161 hasta alındı. Tüm katılımclardan bilgilendirilmiş onam alındı. Bu çalışma, etik kurul izni (Tarih:21.10.2019, Sayı:215) ile Helsinki Beyanı'na uygun olarak yapılmıştır. Tüm MCH'larına MKTF'u ve BAF'u (Türk Tıbbi Onkoloji Derneği tarafından düzenlenen ve modifiye edilen) kontrol gruplarına da sadece BAF'ı anketleri yapıldı. Katılımcılar bu formları cevaplayabilecek kognitif fonksiyona sahiptiler. Çalışma denekleri üç gruba ayrıldı. Grup 1: Histoplatolojik olarak mide kanseri tanısı almış kișilerden (n: 81); Grup 2: Fizik muayene ve laboratuar bulguları normal olan, malign risk grubu içinde olmayan (anamnezinde kanser öyküsü olmayan ve 1 . derece yakınlarında kanser bulunmayan, n: 40, Kontrol 1) sağlıklı gönüllülerden; Grup 3: Mide kanseri dışında (kolon kanseri, meme kanseri, akciğer kanseri, mezotelyoma, osteosarkom gibi) herhangi bir malignitesi olan kişilerden seçildi (n: 40, Kontrol 2).

\section{Sosyodemografik Veri Formu ve Besin Gruplarının Tanımlanması}

MKTF'U (1) hastanın kimlik bilgisi, (2) sosyodemografi-sosyoekonomik ve sosyokültürel düzeyi, (3) sigara-alkol anemnezi, (4) beslenme ve ilaç alışkanlıkları, (5) ağız hijyeni, (6) endoskopi-histopatoloji sonuçları, (7) anemnez ve fizik muayene, (8) laboratuar, (9) aldığı tedaviler gibi değişkenleri içeriyordu.

BAF'unda (l) sosyodemografi-sosyokültürelsosyoekonomik düzey, (2) mide rahatsızlık öyküsü, (3) ağız hijyeni, (4) yaşadığı evin koşullan, (5) alkol ve sigara anemnezi, (6) 23 besin ve içecek madde gibi değişkenler bulunmaktaydı. Besin ve içecekler olağan olarak Türk Toplumu'nun beslenme tarzını temsil ediyordu.

\section{Besin Gruplarının Tanımlanması}

BAF'unun 6.değişkeninde ' 23 besin ve içecek madde' analizinde aşağıdaki besin grupları bulunmaktadır: (1) ekmek, (2) et ve et ürünleri (kırmızı et, balık eti, tavuk eti, sosis, sucuk, pastırma), (3) ateş_-közde/-mangalda pişmiş et ürünleri, (4) tuzlanarak saklanmış et ürünleri, (5) çiğ etten yapılmış yiyecekler, (6) tuzlu peynir, (7) turşu, (8) zeytin, (9) tuzlanmış salamura zeytin, (10) çay, (11) çaya katılan şeker, (12) kahve, (13) süt, (14) kırmızı pul biberi, (15) meyve suyu, (16) meyve, (17) sebze, (18) salata, (19) tatlı, (20) yağ, (21) yumurta, (22) yoğurt, (23) kuruyemiş.

\section{Istatistiki Analiz}

Verilerin istatistiksel analizinde International Business Machines (IBM), Statistical Package for the Social Sciences, (SPSS) 22.0 paket programı kullanılmıştır. Çalışmada yer alan kategorik değişkenler ve gruplar arasındaki farklılıklar 'Pearson Chi-Square testi' ile değerlendirildi. P $<0.05$ 'ten küçük değerler istatistiksel olarak anlamlı kabul edildi.

\section{BULGULAR}

MCH'ların demografik ve genel özellikleri (yaș, cinsiyet, meslek, ikamet yeri, öğrenim durumu, gelir düzeyi, kan grubu, sigara-alkol ve beslenme alışkanlıkları, geçirilmiş mide ameliyat öyküsü, ağız hijyeni, diş enfeksiyonu, diş firçalama alışkanlı̆̆ı, tümör evresi ve lokalizasyonu) belirlendi (Tablo I).

Tablo I: MCH'ların demografik ve genel özellikleri

\begin{tabular}{|l|l|c|c|}
\hline Değişkenler & Kategori & $\mathbf{n}$ & $\mathbf{\%}$ \\
\hline \multirow{5}{*}{ Yaş } & $10-19$ & 0 & 0 \\
\cline { 2 - 4 } & $20-29$ & 1 & $(2,1)$ \\
\cline { 2 - 4 } & $30-39$ & 10 & $(12)$ \\
\cline { 2 - 4 } & $40-49$ & 13 & $(16)$ \\
\cline { 2 - 4 } & $50-59$ & 21 & $(26)$ \\
\cline { 2 - 4 } & $60-69$ & 24 & $(29,4)$ \\
\hline
\end{tabular}




\begin{tabular}{|c|c|c|c|}
\hline & $70-79$ & 10 & $(12,2)$ \\
\hline & $80-89$ & 2 & $(2,3)$ \\
\hline \multirow[b]{2}{*}{ Cinsiyet } & Erkek & 56 & $(69,1)$ \\
\hline & Kadın & 25 & $(30,9)$ \\
\hline \multirow{6}{*}{ Meslek } & Çiftçi & 23 & $(28,4)$ \\
\hline & Ev hanımı & 26 & $(32,3)$ \\
\hline & Memur & 8 & $(9,9)$ \\
\hline & Serbest & 9 & (11) \\
\hline & İşçi & 9 & (11) \\
\hline & İnşaatçı & 6 & $(7,4)$ \\
\hline \multirow{3}{*}{ İkamet yeri } & Köy & 15 & $(18,5)$ \\
\hline & İlçe & 32 & $(39,5)$ \\
\hline & İl & 34 & $(42)$ \\
\hline \multirow{6}{*}{ Öğrenim Durumu } & Cahil & 51 & $(63,7)$ \\
\hline & Okur-yazar & 1 & $(1,3)$ \\
\hline & İlkokul & 20 & (25) \\
\hline & Ortaokul & 2 & $(2,5)$ \\
\hline & Lise & 4 & (5) \\
\hline & Üniversite & 2 & $(2,5)$ \\
\hline \multirow{3}{*}{ Gelir düzeyi ${ }^{a}$} & <300 (Düşük) & 54 & (74) \\
\hline & $300-500$ (Orta) & 12 & $(16,4)$ \\
\hline & >500 (Yüksek) & 7 & $(9,6)$ \\
\hline \multirow{4}{*}{ Kan grubu } & A & 26 & $(42,6)$ \\
\hline & B & 10 & $(16,4)$ \\
\hline & $A B$ & 3 & $(4,9)$ \\
\hline & 0 & 22 & $(36,1)$ \\
\hline \multirow{4}{*}{ Alışkanlıklar } & Yok & 48 & $(60,8)$ \\
\hline & Alkol & 0 & 0 \\
\hline & Sigara & 29 & $(36,7)$ \\
\hline & Alkol+Sigara & 2 & $(2,5)$ \\
\hline \multirow[b]{2}{*}{$\begin{array}{l}\text { Beslenme } \\
\text { Alışkanlıkları }\end{array}$} & Normal & 54 & $(70,1)$ \\
\hline & $\begin{array}{l}\text { Sebze-meyve } \\
\text { ağırlıklı }\end{array}$ & 6 & $(7,8)$ \\
\hline
\end{tabular}

\begin{tabular}{|c|c|c|c|}
\hline & Et ağırlıklı & 17 & $(22,1)$ \\
\hline \multirow{2}{*}{$\begin{array}{l}\text { Geçirilmiş } \\
\text { ameliyatı }\end{array}$} & Hayır & 75 & $(92,6)$ \\
\hline & Evet & 6 & $(4,4)$ \\
\hline \multirow[b]{2}{*}{ Ağız hijyeni } & İyi & 37 & $(54,5)$ \\
\hline & Kötü & 31 & $(45,5)$ \\
\hline \multirow{3}{*}{ Diş enfeksiyonu } & Yok & 32 & $(47,1)$ \\
\hline & Var & 20 & $(29,4)$ \\
\hline & Protez & 16 & $(23,5)$ \\
\hline \multirow{4}{*}{$\begin{array}{ll}\text { Dişs } & \text { firçalama } \\
\text { alışkanlığı } & \end{array}$} & Yok & 41 & $(62)$ \\
\hline & Bazen & 16 & $(24)$ \\
\hline & Düzenli & 3 & (5) \\
\hline & Misvak kullanıyor & 6 & (9) \\
\hline \multirow{3}{*}{ Mide lokalizasyonu } & Distal & 3 & $(40,8)$ \\
\hline & Korpus & 2 & $(29)$ \\
\hline & Proksimal & 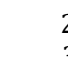 & $(30,2)$ \\
\hline \multirow[b]{2}{*}{ Evre } & Erken & $?$ & $?$ \\
\hline & İleri & 65 & $(80)$ \\
\hline
\end{tabular}

a: Dolar cinsinden hesaplanmış 1 aylık gelir düzeyi, n: Katılımcı Sayısı, \%: Yüzde Oranı

MCH'ların \%69,1'i erkek, \%30,9'u kadındı. MCH'ların \%18,5'i köyde, \%39,5'i ilçede, \%42'si şehirde ikamet ediyordu. MCH grubundaki kadınların tamamı ev hanımıydı. $\mathrm{MCH}$ grubundaki erkeklerin \%28,4'ü çiftçi, \%9,9'u memur, \%11'i serbest, \%11'i işçi, \%7,4'ü inşaat işlerinde çalışıyorlardı. MCH'ların \%63,7 okuma yazma bilmeyen, \%1,3 okur-yazar, \%25 ilkokul, $\% 2,5$ ortaokul, $\% 5$ lise, $\% 2,5$ üniversite statü düzeyindeydi. MCH'ların \%74'ünün aylık gelir düzeyi <300 dolar, \%16,4'ünün 300-500 dolar arası, \%9,6'sinın $>500$ dolar idi.

MCH'ların kan grubu incelendiğinde \%42,6 A, $\% 36,1$ 0, \%16,4 B, \%4,9 AB idi.

MCH'ların \%36,7'i sigara kullanıcısı, \%2,5'i sigara-alkol kullanıcısıydı. MCH'ların \%60,8'inin alkol ve sigara alıșkanlığı yoktu. 
MCH'ların \%70,1 normal, \%7,8 sebze-meyve ağırlıklı, \%22,1 et ağırlıklı besleniyordu.

MCH'ların \%54,5'inin ağız hijyeni iyiydi, $\% 45,5$ 'inin ise kötüydü. Diş enfeksiyonu $\% 47,1$ 'inde yoktu, \%29,4'ünde ise vardı. MCH'ların \%23,5'inde diş protezi vardı. MCH'ların \%62'sinde diş firçalama alışkanlığı yoktu, \%9'ü misvak kullanıyordu. MCH'ların bir kısmı arada bir (\%24), çok az bir kısmının (\%5) ise düzenli diș firçalama alıșkanlığı vardı.

Tümör lokalizasyonu olarak mide distali \%40,8, mide korpusu \%29 ve mide proksimali $\% 30,2$ izlendi. MCH'ların 65 tanesinde ilerlemiş mide kanseri tespit edildi. MCH'larımız içinde erken mide kanseri yoktur.

MCH ve kontrol grupları (kontrol-1 ve 2) yaş, cinsiyet, ikamet yeri, meslek, geçirilmiş mide ameliyatı ve mide rahatsızlı öyküsü, diş fırçalama sıklığı, dişlerde çürük, evin oda sayısı, evde oturanların sayısı, içme suyunun kaynağı, evde buzdolabı bulunup bulunmaması, gelir düzeyi, öğrenim durumu, sigara-alkol öyküsü gibi değişkenler açısından karşılaștırıldı (Tablo II).

Tablo II: Grupların genel özelliklerinin karşılaştırılması

\begin{tabular}{|c|c|c|c|c|c|c|c|c|}
\hline \multirow[b]{2}{*}{$\begin{array}{l}\text { Değişken } \\
\text { ler }\end{array}$} & \multirow[b]{2}{*}{$\begin{array}{l}\text { Katego } \\
\text { ri }\end{array}$} & \multicolumn{2}{|c|}{$\begin{array}{c}\text { MCH } \\
\text { (n:81) }\end{array}$} & \multicolumn{2}{|c|}{$\begin{array}{c}\text { Kontrol-1 } \\
\text { (n:40) }\end{array}$} & \multicolumn{2}{|c|}{$\begin{array}{c}\text { Kontrol-2 } \\
\text { (n:40) }\end{array}$} & \multirow[t]{2}{*}{$\mathrm{P}$} \\
\hline & & $\mathbf{n}$ & $\%$ & $\mathbf{n}$ & $\%$ & $\mathbf{n}$ & $\%$ & \\
\hline \multirow{6}{*}{ Yaş } & $10-19$ & 0 & 0 & 0 & 0 & 3 & $\stackrel{(7,5}{)}$ & \\
\hline & $20-29$ & 1 & $(2,1)$ & $\begin{array}{l}1 \\
2\end{array}$ & (30) & 4 & $\begin{array}{c}(10 \\
)\end{array}$ & \\
\hline & $30-39$ & 10 & (12) & 8 & (20) & 3 & $\begin{array}{c}(7,5 \\
)\end{array}$ & \\
\hline & $40-49$ & 13 & (16) & 7 & $\begin{array}{c}(17, \\
5)\end{array}$ & 8 & $\begin{array}{c}(20 \\
)\end{array}$ & \\
\hline & $50-59$ & 21 & (26) & 7 & $\begin{array}{c}(17, \\
5)\end{array}$ & 8 & $\begin{array}{c}(20 \\
)\end{array}$ & \\
\hline & $60-69$ & 24 & $\begin{array}{c}(29,4 \\
)\end{array}$ & 4 & (10) & 8 & $\begin{array}{c}(20 \\
)\end{array}$ & \\
\hline
\end{tabular}

\begin{tabular}{|c|c|c|c|c|c|c|c|c|}
\hline & $70-79$ & 10 & $(12,2$ & 2 & (5) & 5 & $(12,5)$ & \\
\hline & $80-89$ & 2 & $(2,3)$ & 0 & 0 & 1 & $\begin{array}{c}(2,5 \\
)\end{array}$ & \\
\hline \multirow[b]{2}{*}{ Cinsiyet } & Erkek & 55 & $\begin{array}{c}(67,9 \\
)\end{array}$ & $\begin{array}{l}1 \\
6\end{array}$ & $(40)$ & $\begin{array}{l}2 \\
2\end{array}$ & $\begin{array}{c}(55 \\
)\end{array}$ & \multirow{2}{*}{$\begin{array}{c}, 00 \\
8\end{array}$} \\
\hline & Kadın & 26 & $\begin{array}{c}(32,1 \\
)\end{array}$ & $\begin{array}{l}2 \\
4\end{array}$ & (60) & $\begin{array}{l}1 \\
8\end{array}$ & $\begin{array}{c}(45 \\
)\end{array}$ & \\
\hline \multirow{3}{*}{$\begin{array}{l}\text { İkamet } \\
\text { yeri }\end{array}$} & Köy & 15 & $\begin{array}{c}(18,5 \\
)\end{array}$ & 3 & $\begin{array}{c}(7,7 \\
)\end{array}$ & $\begin{array}{l}1 \\
4\end{array}$ & $\begin{array}{c}(35, \\
9)\end{array}$ & \multirow{3}{*}{$\begin{array}{l}, 00 \\
0\end{array}$} \\
\hline & İlçe & 32 & $\begin{array}{c}(39,5 \\
)\end{array}$ & 5 & $\begin{array}{c}(12, \\
8)\end{array}$ & 5 & $\begin{array}{c}02,8 \\
\text { ) }\end{array}$ & \\
\hline & İl & 34 & $(42)$ & $\begin{array}{l}3 \\
1\end{array}$ & $\begin{array}{l}(79, \\
5)\end{array}$ & $\begin{array}{l}2 \\
0\end{array}$ & $\begin{array}{c}(51, \\
3)\end{array}$ & \\
\hline \multirow{6}{*}{ Meslek } & Çiftçi & 23 & $\begin{array}{c}(28,1 \\
)\end{array}$ & 0 & 0 & 9 & $\begin{array}{c}(22, \\
5)\end{array}$ & \multirow{6}{*}{$\begin{array}{l}, 00 \\
0\end{array}$} \\
\hline & $\begin{array}{l}\text { Ev } \\
\text { hanımı }\end{array}$ & 26 & $\begin{array}{c}(33,0 \\
)\end{array}$ & $\begin{array}{l}1 \\
0\end{array}$ & $\begin{array}{c}(25, \\
6)\end{array}$ & $\begin{array}{l}1 \\
5\end{array}$ & $\begin{array}{c}(37, \\
5)\end{array}$ & \\
\hline & Memur & 8 & $(9,7)$ & $\begin{array}{l}2 \\
7\end{array}$ & $\begin{array}{l}(69, \\
2)\end{array}$ & $\begin{array}{l}1 \\
0\end{array}$ & $\begin{array}{c}(25 \\
)\end{array}$ & \\
\hline & Serbest & 9 & $\begin{array}{l}\text { (11, } \\
1)\end{array}$ & 0 & 0 & 0 & 0 & \\
\hline & İşçi & 9 & (11) & 2 & $(5,2)$ & 6 & (15) & \\
\hline & İnşaatçı & 6 & $(7,1)$ & 0 & 0 & 0 & 0 & \\
\hline \multirow{2}{*}{$\begin{array}{l}\text { Geçirilmi } \\
\text { s mide } \\
\text { ameliyat }\end{array}$} & Hayır & $\begin{array}{l}2 \\
1\end{array}$ & $\begin{array}{l}(52, \\
5)\end{array}$ & $\begin{array}{l}3 \\
8\end{array}$ & (95) & 40 & $\begin{array}{c}(10 \\
0)\end{array}$ & \multirow{2}{*}{$\begin{array}{l}, 00 \\
0\end{array}$} \\
\hline & Evet & 19 & $(47,5)$ & 2 & (5) & 0 & 0 & \\
\hline \multirow{2}{*}{$\begin{array}{l}\text { Mide } \\
\text { Rahatsızl } \\
\text { lk } \\
\text { Öyküsü }\end{array}$} & Hayır & $\begin{array}{l}2 \\
1\end{array}$ & $\begin{array}{c}(52, \\
5)\end{array}$ & $\begin{array}{l}3 \\
8\end{array}$ & $(42,5)$ & 26 & $\begin{array}{c}(66, \\
6)\end{array}$ & \multirow[b]{2}{*}{$\begin{array}{l}, 00 \\
0\end{array}$} \\
\hline & Evet & 19 & $(47,5)$ & 2 & $(57,5)$ & 13 & $\begin{array}{c}(33, \\
4)\end{array}$ & \\
\hline \multirow{5}{*}{$\begin{array}{l}\text { Dişlerin } \\
\text { fırçalama } \\
\text { alışkanlı } \\
\text { ğı }\end{array}$} & Her gün & 4 & $\begin{array}{c}(12, \\
5)\end{array}$ & $\begin{array}{l}2 \\
9\end{array}$ & $(85,3)$ & 9 & (29) & \multirow{5}{*}{,00 } \\
\hline & $\begin{array}{l}3-5 \\
\text { gün/w }\end{array}$ & 8 & (25) & 2 & $(5,9)$ & 7 & $\begin{array}{l}(22, \\
6)\end{array}$ & \\
\hline & $\begin{array}{l}1-2 \\
\text { gün/w }\end{array}$ & 3 & $\begin{array}{c}(9,3 \\
)\end{array}$ & 1 & $(2,9)$ & 6 & $\begin{array}{c}(19, \\
4)\end{array}$ & \\
\hline & $\begin{array}{l}1-2 \\
\text { gün/m }\end{array}$ & 6 & $\begin{array}{l}(18, \\
8)\end{array}$ & 0 & 0 & 4 & $\begin{array}{c}\text { (12, } \\
1)\end{array}$ & \\
\hline & $\begin{array}{l}1-2 \\
\text { gün/y }\end{array}$ & $\begin{array}{l}1 \\
1\end{array}$ & $\begin{array}{c}(34, \\
4)\end{array}$ & 2 & $(5,9)$ & 5 & $\begin{array}{l}(16, \\
1)\end{array}$ & \\
\hline
\end{tabular}




\begin{tabular}{|c|c|c|c|c|c|c|c|c|}
\hline \multirow{2}{*}{$\begin{array}{l}\text { Dişlerde } \\
\text { çürük }\end{array}$} & Hayır & 5 & $\begin{array}{c}(12, \\
8)\end{array}$ & $\begin{array}{l}1 \\
1\end{array}$ & (29) & 9 & $\begin{array}{l}(24, \\
3)\end{array}$ & \multirow{2}{*}{$\begin{array}{l}, 30 \\
6\end{array}$} \\
\hline & Evet & $\begin{array}{l}3 \\
4\end{array}$ & $\begin{array}{c}(87, \\
2)\end{array}$ & $\begin{array}{l}2 \\
7\end{array}$ & (71) & 28 & $\begin{array}{c}(75, \\
7)\end{array}$ & \\
\hline \multirow{4}{*}{$\begin{array}{l}\text { Evin oda } \\
\text { sayısı }\end{array}$} & 1 odalı & 2 & (5) & 0 & 0 & 0 & 0 & \multirow{4}{*}{$\begin{array}{l}, 01 \\
4\end{array}$} \\
\hline & 2 odalı & $\begin{array}{l}1 \\
2\end{array}$ & (30) & 6 & (15) & 6 & $\begin{array}{c}(15 \\
)\end{array}$ & \\
\hline & 3 odalı & $\begin{array}{l}1 \\
8\end{array}$ & (45) & $\begin{array}{l}1 \\
1\end{array}$ & $(27,5)$ & 15 & $\begin{array}{c}(37, \\
5)\end{array}$ & \\
\hline & $>3$ odalı & 8 & (20) & $\begin{array}{l}2 \\
3\end{array}$ & $(27,5)$ & 19 & $\begin{array}{c}(47, \\
5)\end{array}$ & \\
\hline \multirow{4}{*}{$\begin{array}{l}\text { Evde } \\
\text { oturanlar } \\
\text { in sayısı }\end{array}$} & $1-3$ & 5 & $\begin{array}{c}(12, \\
5)\end{array}$ & $\begin{array}{l}2 \\
0\end{array}$ & $(50)$ & 2 & (5) & \multirow{4}{*}{$\begin{array}{l}, 00 \\
0\end{array}$} \\
\hline & $4-5$ & $\begin{array}{l}1 \\
2\end{array}$ & (30) & 8 & $(20)$ & 7 & $\begin{array}{c}(17, \\
5)\end{array}$ & \\
\hline & $6-10$ & $\begin{array}{l}1 \\
6\end{array}$ & $(40)$ & $\begin{array}{l}1 \\
0\end{array}$ & $(25)$ & 17 & $(42,5)$ & \\
\hline & $>10$ & 7 & $\begin{array}{c}(17, \\
5)\end{array}$ & 2 & (5) & 14 & (35) & \\
\hline \multirow{3}{*}{$\begin{array}{l}\text { İçme } \\
\text { suyun } \\
\text { kaynağı }\end{array}$} & $\begin{array}{l}\text { Şehir } \\
\text { șebekes } \\
\text { i }\end{array}$ & $\begin{array}{l}2 \\
6\end{array}$ & (65) & $\begin{array}{l}4 \\
0\end{array}$ & $(100)$ & 28 & (70) & \multirow{3}{*}{$\begin{array}{l}, 00 \\
0\end{array}$} \\
\hline & $\begin{array}{l}\text { Kuyu } \\
\text { suyu }\end{array}$ & 6 & (15) & 0 & 0 & 5 & $\begin{array}{c}(12, \\
5)\end{array}$ & \\
\hline & $\begin{array}{l}\text { Köy } \\
\text { çeşmesi }\end{array}$ & 8 & (20) & 0 & 0 & 7 & $\begin{array}{c}(17, \\
5)\end{array}$ & \\
\hline \multirow{2}{*}{$\begin{array}{l}\text { Evde } \\
\text { buzdolab } \\
\text { I }\end{array}$} & Var & $\begin{array}{l}3 \\
7\end{array}$ & $\begin{array}{c}(92, \\
5)\end{array}$ & $\begin{array}{l}4 \\
0\end{array}$ & $(100)$ & 36 & $(90)$ & \multirow{2}{*}{$\begin{array}{l}, 12 \\
4\end{array}$} \\
\hline & Yok & 2 & $(7,5)$ & 0 & 0 & 4 & (10) & \\
\hline \multirow{6}{*}{$\begin{array}{l}\text { Gelir } \\
\text { düzeyi }\end{array}$} & $<500$ & $\begin{array}{l}3 \\
1\end{array}$ & $\begin{array}{c}(79, \\
5)\end{array}$ & 9 & (23) & 19 & $\begin{array}{c}(48, \\
7)\end{array}$ & \multirow{6}{*}{$\begin{array}{l}, 00 \\
0\end{array}$} \\
\hline & $\begin{array}{l}500- \\
1000\end{array}$ & 7 & (18) & $\begin{array}{l}1 \\
2\end{array}$ & $(30,8)$ & 13 & $\begin{array}{l}(33, \\
3)\end{array}$ & \\
\hline & $\begin{array}{l}1000- \\
1500\end{array}$ & 1 & $(2,5)$ & $\begin{array}{l}1 \\
1\end{array}$ & $(28,2)$ & 6 & $\begin{array}{c}(15, \\
4)\end{array}$ & \\
\hline & $>1500$ & & & & (18) & & $\begin{array}{c}(2,6 \\
)\end{array}$ & \\
\hline & $\begin{array}{l}\text { Okur- } \\
\text { yazar } \\
\text { değil }\end{array}$ & 21 & $\begin{array}{c}(52,5 \\
)\end{array}$ & 4 & (10) & 18 & $(45)$ & \\
\hline & $\begin{array}{l}\text { Okur- } \\
\text { yazar }\end{array}$ & 5 & $\begin{array}{c}(12,5 \\
)\end{array}$ & 5 & $\begin{array}{l}(12, \\
5)\end{array}$ & 3 & $\begin{array}{c}(7,5 \\
)\end{array}$ & \\
\hline
\end{tabular}

\begin{tabular}{|c|c|c|c|c|c|c|c|c|}
\hline \multirow[t]{4}{*}{$\begin{array}{l}\text { Öğrenim } \\
\text { durumu }\end{array}$} & İlkokul & 9 & $\begin{array}{c}(22,5 \\
)\end{array}$ & 3 & $(7,5)$ & 8 & $\begin{array}{c}(20 \\
)\end{array}$ & \multirow[t]{4}{*}{$\begin{array}{l}, 00 \\
0\end{array}$} \\
\hline & $\begin{array}{l}\text { Orta } \\
\text { okul }\end{array}$ & 1 & $(2,5)$ & 3 & $(7,5)$ & 4 & $\begin{array}{c}(10 \\
)\end{array}$ & \\
\hline & Lise & 3 & $(7,5)$ & 5 & $\begin{array}{c}\text { (12, } \\
5)\end{array}$ & 4 & $\begin{array}{c}(10 \\
)\end{array}$ & \\
\hline & $\begin{array}{l}\text { Üniversi } \\
\text { te }\end{array}$ & 1 & $(2,5)$ & 20 & $(50)$ & 3 & $(7,5)$ & \\
\hline \multirow[b]{2}{*}{ Sigara } & Hayır & 19 & $\begin{array}{c}(47,5 \\
)\end{array}$ & $\begin{array}{l}2 \\
3\end{array}$ & $\begin{array}{c}(57, \\
5)\end{array}$ & 17 & $(42,5)$ & \multirow{2}{*}{$\begin{array}{l}, 00 \\
0\end{array}$} \\
\hline & Evet & 11 & $\begin{array}{c}(27,5 \\
)\end{array}$ & $\begin{array}{l}1 \\
3\end{array}$ & $\begin{array}{c}(32, \\
5)\end{array}$ & 13 & $(32,5)$ & \\
\hline \multirow{7}{*}{ Alkol } & $\begin{array}{l}\text { İçmiş- } \\
\text { bırakmı } \\
\text { ş }\end{array}$ & 10 & (25) & 4 & (10) & 10 & $\begin{array}{c}(25 \\
)\end{array}$ & \multirow{7}{*}{$\begin{array}{l}, 53 \\
1\end{array}$} \\
\hline & $\begin{array}{l}\text { İçmedi } \\
\text { m }\end{array}$ & 35 & $\begin{array}{c}(87,5 \\
)\end{array}$ & $\begin{array}{l}3 \\
2\end{array}$ & $(80)$ & 34 & $\begin{array}{c}(85 \\
)\end{array}$ & \\
\hline & Her gün & 2 & (5) & 1 & $(2,5)$ & 2 & (5) & \\
\hline & $\begin{array}{l}3-5 \\
\text { gün/w }\end{array}$ & 0 & 0 & 0 & 0 & 1 & $\begin{array}{c}(2,5 \\
)\end{array}$ & \\
\hline & $\begin{array}{l}1-2 \\
\text { gün/w }\end{array}$ & 3 & $(7,5)$ & 3 & $(7,5)$ & 1 & $\stackrel{(2,5}{)}$ & \\
\hline & $\begin{array}{l}1-2 \\
\text { gün/m }\end{array}$ & 0 & 0 & 2 & (5) & 1 & $\stackrel{(2,5}{)}$ & \\
\hline & $\begin{array}{l}1-2 \\
\text { gün/y }\end{array}$ & 0 & 0 & 2 & (5) & 1 & $\stackrel{(2,5}{)}$ & \\
\hline
\end{tabular}

b: Dolar cinsinden hesaplanmıș 1 aylık gelir düzeyi P; Pearson Chi-Square testi m: ay, w: hafta y: yıl

Her iki kanser grubunda ileri yaşlılık, sağlıklı gönüllü bireylerde daha çok genç yaşlılık baskındı. Kontrol 1 grubunun \%40's erkek, \%55'i kadındı. Kontrol 2 grubunun ise \% 60' 1 erkek, \%45'i kadındı. MCH ve kontrol-2 grubunda erkek cinsiyet ( $\% 67,9, \% 55$, sirasiyla) daha fazla iken kontrol-l'de kadınlar (\%60) daha fazlaydı. MCH'larda erkek cinsiyet istatistiksel olarak anlamlı derecede daha fazlaydl $\quad(p<0,05), \quad$ Kontrol-1 grubunun çoğunluğu $(\% 79,5)$ kentlerde oturuyordu ( $p>0,05)$. MCH'larda ise kırsal yaşam baskındı. Kontrol-2 ise daha çok kent merkezinde $(\% 51,3)$ oturuyordu. MCH'ların çoğunluğu ev hanımı (\%33) ve çiftçiydi (\%28,l). Kontrol-1'de çoğunluğu memurlar (\%69,2; $(p<0,05)$, kontrol- 
2'ise çoğunluğu ev hanımları $(\% 37,5)$ oluşturuyordu. MCH'larda baskın olan meslek grubu; ev hanımı ve çiftçilik mesleği idi.

Günlük diş firçalama alışkanlığı kontrol-l'de $(\% 85,3 ; \mathrm{p}<0,05)$ anlamlı derecede fazlaydı. MCH ve kontrol-2 grubu daha az oranda günlük fırçalama sıklıklarına sahiplerdi $(\% 12,5, \% 29$, sirasiyla). Kontrol-l grubu ile karşılaştırıldığında $\mathrm{MCH}$ ve kontrol-2 gruplarının günlük düzenli diş fırçalama alışkanlıkları bulunmuyordu. Diş çürüğü oranları her üç grupta birbirine benzerdi, istatistiksel anlamlılık taşımıyordu ( $p>0,05)$.

MCH'ların \%40'ında, kontrol-2'lerin \%42,5'inde evinde oturan kişi sayısı 6-10 arasındayken, kontrol-l'lerin evinde oturan kişi sayısı \%50 $(\mathrm{p}<0,05)$ oranında 1-3 arasında izleniyordu. Mide kanseri ile kalabalık ortamda yaşayanların arasında istatiksel anlamlılık içerisinde bir ilişki vardı $(\mathrm{p}<0,05)$.

Aylık gelir düzeyi MCH'ların \%79,5'inde $<500$ dolar, kontrol- l'in \%30,8'inde 500-1500 dolar arasinda, kontrol-2'in \%48,7'sinde $<500$ dolar $(\mathrm{p}<0.05)$ idi.

MCH'larımızın \%52,5'i okur-yazar olmayan, kontrol-l'in \%50'si üniversite mezunu, kontrol2 'nin $\% 45$ 'i cahil $(\mathrm{p}<0,05)$ idi. MCH ve kontrol-2 gruplarının sosyoekonomik ve sosyokültürel düzeyi istatistiksel anlamlılık içerisinde daha düşüktü $(\mathrm{p}<0,05)$.

MCH'ların \%47,5'i, kontrol-l'in \%57,5'i, kontrol2 'in $\% 42,5$ 'i sigara içmiyordu $(\mathrm{p}<0,05)$. Sigara içimi her iki kanser grubunda istatiksel olarak anlamlı değildi. Gruplar arasında alkol tüketimi açısından istatiksel anlamlılık tespit edilmedi ( $p>0,05)$.

MKH ve kontrol grupları (kontrol-1 ve 2) yediği ekmek sayısı/gün, ekmeğin pişirildiği yer, et-et ürünleri, tütsülenmiş et ürünleri, sucukpastırma-sosis yeme, tuzlanarak saklanmış et ürünleri yeme, çiğ etten yapılmış yiyecekler yeme, tuzlu peynir yeme, turşu yeme, tuzlanmış salamuralı zeytin yeme, çay içme, çaya katılan şeker miktarı, kahve içme, süt içme, kırmızı pul biberi kullanımı, meyve suyu içme, meyve yeme, sebze tüketme, salata yeme, tatlı, kullanılan yağ türü, ailenin aylı yağ tüketimi, yumurta yeme, yoğurt yeme ve kuruyemiş yeme gibi beslenme değişkenleriyle karşılaştırıldı (Tablo III).

Tablo III: Beslenme özelliklerinin karşılaştırması

\begin{tabular}{|c|c|c|c|c|c|c|c|c|}
\hline \multirow[b]{2}{*}{$\begin{array}{l}\text { Değişkenle } \\
\text { r }\end{array}$} & \multirow[b]{2}{*}{ Kategori } & \multicolumn{2}{|c|}{$\begin{array}{l}\text { MCH } \\
(\mathrm{n}: 81)\end{array}$} & \multicolumn{2}{|c|}{$\begin{array}{c}\text { Kontrol-1 } \\
\text { (n:40) }\end{array}$} & \multicolumn{2}{|c|}{$\begin{array}{c}\text { Kontrol-2 } \\
\text { (n:40) }\end{array}$} & \multirow[t]{2}{*}{$P$} \\
\hline & & $\mathrm{n}$ & $\%$ & $\mathrm{n}$ & $\%$ & $\mathbf{n}$ & $\%$ & \\
\hline \multirow{4}{*}{$\begin{array}{l}\text { Yediği } \\
\text { ekmek } \\
\text { sayısı/gün }\end{array}$} & $<1$ ekmek & $\begin{array}{l}2 \\
0\end{array}$ & $(50)$ & 23 & $(57,5)$ & $\begin{array}{l}1 \\
6\end{array}$ & $(40)$ & \multirow{4}{*}{,331 } \\
\hline & $\begin{array}{ll}1 & \text { ekmek } \\
(350 & \text { gr) }\end{array}$ & 6 & (15) & 10 & $\begin{array}{c}(25 \\
)\end{array}$ & 8 & (20) & \\
\hline & $\begin{array}{l}2 \quad \text { ekmek } \\
(700 \mathrm{gr})\end{array}$ & $\begin{array}{l}1 \\
1\end{array}$ & $(27,5)$ & 6 & (15) & $\begin{array}{l}1 \\
4\end{array}$ & (35) & \\
\hline & $\begin{array}{l}>3 \text { ekmek } \\
(>1050 \text { gr })\end{array}$ & 3 & $(7,5)$ & 1 & $(2,5)$ & 2 & (5) & \\
\hline \multirow{3}{*}{$\begin{array}{l}\text { Ekmeğin } \\
\text { pişirildiği } \\
\text { yer }\end{array}$} & $\begin{array}{l}\text { Tandır } \\
\text { fırını }\end{array}$ & $\begin{array}{l}2 \\
2\end{array}$ & (55) & 4 & $\begin{array}{c}(10 \\
)\end{array}$ & 17 & $(43,6)$ & \multirow{3}{*}{,000 } \\
\hline & Firın & $\begin{array}{l}1 \\
3\end{array}$ & $\begin{array}{c}(32,5 \\
)\end{array}$ & 29 & $(72,5)$ & 14 & $(35,9)$ & \\
\hline & $\begin{array}{l}\text { Firın+tand } 1 \\
\mathrm{r} \text { firın }\end{array}$ & 5 & $\begin{array}{c}(12,5 \\
)\end{array}$ & 7 & $(17,5)$ & 8 & $(20,5)$ & \\
\hline \multirow{5}{*}{$\begin{array}{l}\text { Et ve et } \\
\text { ürünleri } \\
\text { yeme }\end{array}$} & Her gün & 2 & $(5,6)$ & 12 & $(30,8)$ & 1 & $(2,6)$ & \multirow{5}{*}{, 001 } \\
\hline & 3-5 gün/w & 8 & $\begin{array}{c}(22,2 \\
)\end{array}$ & 11 & $(28,2)$ & 7 & (18) & \\
\hline & 1-2 gün/w & $\begin{array}{l}1 \\
4\end{array}$ & $\begin{array}{c}(38,9 \\
)\end{array}$ & 12 & $(30,8)$ & 24 & $(61,5)$ & \\
\hline & 1-2 gün/m & 9 & (25) & 4 & $(10,2)$ & 5 & $(12,8)$ & \\
\hline & 1-2 gün/y & 3 & $(8,3)$ & 0 & 0 & 2 & $(5,1)$ & \\
\hline \multirow{5}{*}{$\begin{array}{l}\text { Tütsülenmi } \\
\text { Ş et } \\
\text { ürünleri } \\
\text { yeme }\end{array}$} & Her gün & 1 & $(2,9)$ & 0 & 0 & 1 & $(2,5)$ & \multirow{5}{*}{,289 } \\
\hline & 3-5 gün/w & 1 & $(2,9)$ & 3 & $(7,9)$ & 5 & $(12,5)$ & \\
\hline & 1-2 gün/w & $\begin{array}{l}1 \\
0\end{array}$ & $\begin{array}{c}(29,5 \\
)\end{array}$ & 10 & $(26,3)$ & 9 & $(22,5)$ & \\
\hline & 1-2 gün /m & 8 & $\begin{array}{c}(23,5 \\
)\end{array}$ & 18 & $(47,4)$ & 13 & $(32,5)$ & \\
\hline & 1-2 gün/y & 14 & $\begin{array}{c}(41,2 \\
)\end{array}$ & 7 & $(18,4)$ & 12 & (30) & \\
\hline \multirow{3}{*}{$\begin{array}{l}\text { Sucuk, } \\
\text { pastırma, }\end{array}$} & Her gün & 0 & 0 & 0 & 0 & 3 & $(11,1)$ & \\
\hline & 3-5 gün/w & 1 & $(4,6)$ & 4 & $(12,1)$ & 2 & $(7,4)$ & \\
\hline & I-2 gün/w & 2 & (9) & 9 & $(27,3)$ & 4 & $(14,8)$ & \\
\hline
\end{tabular}




\begin{tabular}{|c|c|c|c|c|c|c|c|c|c|c|c|c|c|c|c|c|c|}
\hline \multirow{2}{*}{$\begin{array}{l}\text { sosis } \\
\text { yeme }\end{array}$} & 1-2 gün/m & 6 & $(27,3)$ & 9 & $(27,3)$ & 6 & $(22,2)$ & \multirow{2}{*}{ 156 } & & 1-2 gün/m & 2 & $(5,4)$ & 0 & 0 & 0 & 0 & \multirow[t]{2}{*}{,351 } \\
\hline & 1-2 gün/y & 13 & $(59,1)$ & 11 & $(33,3)$ & 12 & $(44,5)$ & & & 1-2 gün/y & 0 & 0 & 0 & 0 & 0 & 0 & \\
\hline \multirow{5}{*}{$\begin{array}{l}\text { Tuzlanıp- } \\
\text { saklanmış } \\
\text { et ürünleri } \\
\text { yeme }\end{array}$} & Her gün & 1 & $(5,6)$ & 3 & (25) & I & $(4,7)$ & \multirow{5}{*}{,021 } & \multirow{8}{*}{$\begin{array}{l}\text { Çaya } \\
\text { katılan } \\
\text { şeker } \\
\text { miktarı }\end{array}$} & $\begin{array}{l}0-1 \text { kesme } \\
\text { șeker } \quad<<1\end{array}$ & 6 & $(16,2)$ & 11 & $(29,7)$ & 9 & $(24,3)$ & \\
\hline & 3-5 gün/w & 0 & 0 & 1 & $(8,3$ & 3 & $(14,3)$ & & & tatil & & & & & & & \\
\hline & & 4 & $(22,2)$ & 2 & $(16,6)$ & 9 & $(42,9)$ & & & $\begin{array}{ll}1 & \text { kesme } \\
\text { seker }(1 \\
\text { tatlı kası̆ğ })\end{array}$ & 7 & $(18,9)$ & 6 & $(16,2)$ & 6 & $(16,2)$ & \\
\hline & 1-2 gün/m & 2 & $(11,1)$ & 4 & $(33,5)$ & 5 & $(23,8)$ & & & $2 \quad$ kesme & & & & & 1 & &, 592 \\
\hline & 1-2 gün/y & 11 & $(61,1)$ & 2 & $(16,6)$ & 3 & $(14,3)$ & & & tatlı kaşı̆̆ı) & 10 & $(10,)_{1}$ & 10 & {$[0,000)$} & 8 & {$\left[(10,)^{2}\right.$} & \\
\hline \multirow{6}{*}{$\begin{array}{l}\text { Çiğ etten } \\
\text { yapılmış } \\
\text { yiyecekler } \\
\text { yeme }\end{array}$} & Her gün & 0 & 0 & 0 & 0 & 1 & (4) & \multirow{6}{*}{,369 } & & $\begin{array}{l}3 \quad \text { kesme } \\
\text { șeker }(3\end{array}$ & 5 & $(13,5)$ & 5 & $(13,1)$ & 1 & $(2,7)$ & \\
\hline & 3-5 gün/w & 1 & $(4,6)$ & 2 & $\stackrel{(6,3}{)}$ & 1 & (4) & & & tatlı kaşığı) & & & & & & & \\
\hline & 1-2 gün/w & 2 & (9) & 1 & $\stackrel{(3,1}{)}$ & 3 & $\stackrel{(12}{)}$ & & & $\begin{array}{l}>3 \quad \text { kesme } \\
\text { şeker }\end{array}$ & 1 & $(2,7)$ & 2 & $\begin{array}{c}(5,4 \\
)\end{array}$ & 3 & $(8,1)$ & \\
\hline & & & & & & & & & \multirow{5}{*}{ Kahve içme } & Her gün & 1 & (5) & 4 & $(13,3)$ & 1 & $(3,3)$ & \multirow{5}{*}{,001 } \\
\hline & 1-2 gün/m & 8 & $(36,4)$ & 21 & $(65,6)$ & 11 & ) & & & 3-5 gün/w & 1 & (5) & 10 & $(33,4)$ & 4 & $(13,3)$ & \\
\hline & 1-2 gün/y & 11 & (50) & 8 & (25) & 9 & $\stackrel{(36}{)}$ & & & 1-2 gün/w & 3 & (15) & 9 & (30) & 11 & $(36,7)$ & \\
\hline \multirow{5}{*}{$\begin{array}{l}\text { Tuzlu } \\
\text { peynir } \\
\text { yeme }\end{array}$} & Her gün & 12 & $(35,3)$ & 26 & $(74,3)$ & 24 & $(72,7)$ & \multirow{5}{*}{,005 } & & 1-2 gün/'m & 8 & $(40)$ & 6 & (20) & 13 & $(43,4)$ & \\
\hline & 3-5 gün/w & 12 & $(35,3)$ & 3 & $(8,6)$ & 8 & $(24,2)$ & & & I -2 gün/y & 7 & (35) & 1 & $\stackrel{(3,3}{)}$ & 1 & $(3,3)$ & \\
\hline & 1-2 gün/w & 7 & $(20,6)$ & 5 & $(14,2)$ & 1 & $(3,1)$ & & \multirow{5}{*}{ Süt içme } & Her gün & 7 & $(23,3)$ & 2 & (9) & 4 & $(12,3)$ & \multirow{5}{*}{,113 } \\
\hline & 1-2 gün/m & 3 & $(8,8)$ & 1 & $\begin{array}{c}(2,9 \\
)\end{array}$ & 0 & 0 & & & 3-5 gün/w & 12 & $(40)$ & 6 & $(27,3)$ & 6 & $(20)$ & \\
\hline & 1-2 gün/y & 0 & 0 & 0 & 0 & 0 & 0 & & & 1-2 gün/w & 6 & $(20)$ & 10 & $(45,5)$ & 11 & $(36,7)$ & \\
\hline \multirow{7}{*}{$\begin{array}{l}\text { Turşu } \\
\text { yeme }\end{array}$} & Her gün & 2 & (6) & 7 & $(21,9)$ & 4 & $(11,4)$ & \multirow{7}{*}{,241 } & & 1-2 gün/m & 2 & $(6,7)$ & 4 & $(18,2)$ & 8 & $(27,7)$ & \\
\hline & 3-5 gün/w & 5 & $(15,2)$ & 5 & $(15,6)$ & 10 & $(28,6)$ & & & 1-2 gün/y & 3 & $(10)$ & 0 & 0 & 1 & $(3,3)$ & \\
\hline & 1-2 оӥп/W & 13 & (394) & 15 & $(469)$ & 14 & $(40$ & & \multirow{8}{*}{$\begin{array}{l}\text { Kırmızı pul } \\
\text { biberi } \\
\text { kullanımı }\end{array}$} & Her gün & 6 & (24) & 15 & $(46,9)$ & 14 & $(46,7)$ & \multirow{8}{*}{$\begin{array}{l}, 018 \\
1\end{array}$} \\
\hline & & & & & & & & & & 3-5 gün/w & 4 & (16) & 13 & $(40,6)$ & 6 & $(20)$ & \\
\hline & 1-2 gün/m & 11 & $(33,3)$ & 5 & $(15,6)$ & 6 & $(17,1)$ & & & 1-2 аӥп/w & 6 & (24) & 2 & $(6,3$ & 5 & (16 7) & \\
\hline & 1-2 gün/y & 2 & $(6,1)$ & 0 & 0 & 1 & $(2,9$ & & & & & & & & & & \\
\hline & & & & & & & & & & I gün/w & 3 & $(12)$ & I & $\begin{array}{c}(3,1 \\
)\end{array}$ & 1 & $(3,3)$ & \\
\hline \multirow{5}{*}{$\begin{array}{l}\text { Tuzlanmış } \\
\text { salamura } \\
\text { zeytin } \\
\text { yeme }\end{array}$} & Her gün & 3 & $(10,7)$ & 19 & $(57,6)$ & 12 & $(33,3)$ & \multirow{5}{*}{,001 } & & & & & & & & & \\
\hline & 3-5 gün/w & 12 & $(42,9)$ & 6 & $(18,2)$ & 10 & $(27,8)$ & & & 1-2 gün/m & 5 & (20) & 1 & $\stackrel{(3,1}{)}$ & 3 & (10) & \\
\hline & 1-2 gün/w & 7 & (25) & 8 & $(24,2)$ & 13 & $(36,1)$ & & & 1-2 gün/y & 1 & (4) & 0 & 0 & 1 & $(3,3)$ & \\
\hline & 1-2 gün/m & 5 & $(17,8)$ & 0 & 0 & 0 & 0 & & \multirow{5}{*}{$\begin{array}{l}\text { Meyve suyu } \\
\text { içme }\end{array}$} & Her gün & 3 & $(10,3)$ & 3 & $(10,3)$ & 6 & $(17,7)$ & \multirow{5}{*}{ 083 } \\
\hline & 1-2 gün/y & 1 & $(0,6)$ & 0 & 0 & 1 & $\stackrel{(2,8}{)}$ & & & 3-5 gün/w & 4 & $\begin{array}{c}(13,8 \\
)\end{array}$ & 6 & $(20,7)$ & 7 & $(20,5)$ & \\
\hline \multirow[b]{3}{*}{ Çay içme } & Her gün & 33 & $(89,2)$ & 36 & $(94,7)$ & 37 & $(94,9)$ & & & 1-2 gün/w & 7 & $(24,2$ & 6 & $(20,7)$ & 12 & $(35,3)$ & \\
\hline & 3-5 gün/w & 1 & $(2,7)$ & 2 & $(5,3)$ & 2 & $(5,1)$ & & & & & & & & & & \\
\hline & I-2 gün/w & 1 & $(2,7)$ & 0 & 0 & 0 & 0 & & & 1 gün/w & 4 & $\begin{array}{c}(13,8 \\
)\end{array}$ & 8 & $(27,6)$ & 3 & $(8,8)$ & \\
\hline
\end{tabular}




\begin{tabular}{|c|c|c|c|c|c|c|c|c|}
\hline & 1-2 gün/m & 4 & $\begin{array}{c}(13,8 \\
)\end{array}$ & 6 & $(20,7)$ & 4 & $(13,8)$ & \\
\hline & 1-2 gün/y & 7 & $(24,1)$ & 0 & 0 & 2 & $(5,9)$ & \\
\hline \multirow{6}{*}{$\begin{array}{l}\text { Meyve } \\
\text { yeme }\end{array}$} & Her gün & 4 & $(11,4)$ & 20 & $(51,3)$ & 13 & $(33,3)$ & \multirow{6}{*}{ 004 } \\
\hline & 3-5 gün/w & 8 & $(22,8)$ & 12 & $(30,8)$ & 14 & $(35,9)$ & \\
\hline & 1-2 gün/w & 13 & $(37,2)$ & 6 & $(15,4)$ & 8 & $(20,5)$ & \\
\hline & 1 gün/w & 6 & $(17,1)$ & 0 & 0 & 3 & $(7,7)$ & \\
\hline & 1-2 gün/in & 3 & $(8,6)$ & 1 & $\stackrel{(2,5}{)}$ & 0 & 0 & \\
\hline & 1-2 gün/y & 1 & $(2,9)$ & 0 & 0 & 1 & $(2,6)$ & \\
\hline \multirow{6}{*}{$\begin{array}{l}\text { Sebze } \\
\text { tüketme }\end{array}$} & Her gün & 10 & $(28,6)$ & 24 & $(61,5)$ & 18 & $(47,4)$ & \multirow{6}{*}{,140 } \\
\hline & 3-5 gün/w & 10 & $(28,6)$ & 9 & $(23,4)$ & 8 & (21) & \\
\hline & 1-2 gün/w & 11 & $(31,4)$ & 6 & $(15,1)$ & 9 & $(23,7)$ & \\
\hline & I gün/w & 3 & $(8,6)$ & 0 & 0 & 3 & $(7,9)$ & \\
\hline & 1-2 gün/m & 0 & 0 & 0 & 0 & 0 & 0 & \\
\hline & 1-2 gün/y & 1 & $(2,8)$ & 0 & 0 & 0 & 0 & \\
\hline \multirow{6}{*}{$\begin{array}{l}\text { Salata } \\
\text { yeme }\end{array}$} & Her gün & 3 & $(8,6)$ & 18 & (50) & 9 & $(24,3)$ & \multirow{6}{*}{,001 } \\
\hline & 3-5 gün/w & 11 & $(31,4)$ & 11 & $(30,6)$ & 19 & $(51,4)$ & \\
\hline & I-2 gün/w & 8 & $(22,9)$ & 6 & $(16,6)$ & 6 & $(16,2)$ & \\
\hline & 1 gün/w & 6 & $(17,1)$ & 1 & $\stackrel{(2,8}{)}$ & 2 & $(5,4)$ & \\
\hline & 1-2 gün/m & 5 & $(14,3)$ & 0 & 0 & 1 & $(2,7)$ & \\
\hline & I-2 gün/y & 2 & $(5,7)$ & 0 & 0 & 0 & 0 & \\
\hline \multirow{6}{*}{ Tatlı yeme } & Her gün & 2 & $(6,1)$ & 2 & $(5,7)$ & 2 & $(5,4)$ & \multirow{6}{*}{,806 } \\
\hline & 3-5 gün/w & 3 & (9) & 4 & $(11,4)$ & 5 & $(13,5)$ & \\
\hline & 1-2 gün/w & 7 & $(21,2)$ & 9 & $(25,7)$ & 13 & $(35,2)$ & \\
\hline & 1 gün/w & 7 & $(21,2)$ & 10 & $(28,6)$ & 9 & $(24,3)$ & \\
\hline & 1-2 gün/m & 12 & $(36,4)$ & 10 & $(28,6)$ & 7 & $(18,9)$ & \\
\hline & 1-2 gün/y & 2 & $(6,1)$ & 0 & 0 & 1 & $(2,7)$ & \\
\hline \multirow{6}{*}{$\begin{array}{l}\text { Kullanılan } \\
\text { yağ türü }\end{array}$} & $\begin{array}{l}\text { Katı } \\
\text { margarin }\end{array}$ & 14 & (35) & 1 & $\stackrel{(2,6}{)}$ & 12 & $(30,8)$ & \multirow{6}{*}{, 000} \\
\hline & Zeytin yağ & 5 & $(12,5)$ & 12 & $(31,6)$ & 5 & $(12,8)$ & \\
\hline & $\begin{array}{l}\text { Diğer sıvı } \\
\text { yağlar }\end{array}$ & 14 & (35) & 15 & $(39,5)$ & 14 & $(35,9)$ & \\
\hline & $\begin{array}{l}\text { Katı+sıvı } \\
\text { yağ }\end{array}$ & 6 & (15) & 10 & $(26,3)$ & 8 & $(20,5)$ & \\
\hline & Tereyağı & 1 & $(2,5)$ & 0 & 0 & 0 & 0 & \\
\hline & $<5$ kg-litre & 13 & $(33,3)$ & 26 & $(68,4)$ & 6 & $(15,4)$ & \\
\hline
\end{tabular}

\begin{tabular}{|c|c|c|c|c|c|c|c|c|}
\hline \multirow{4}{*}{$\begin{array}{l}\text { Ailenin } \\
\text { aylı yağ } \\
\text { tüketimi }\end{array}$} & $\begin{array}{ll}5-10 & \mathrm{~kg}- \\
\text { litre } & \end{array}$ & 12 & $(30,8)$ & 5 & $(13,2)$ & 8 & $(20,5)$ & \multirow{4}{*}{, 000} \\
\hline & $\begin{array}{l}10-15 \quad k g- \\
\text { litre }\end{array}$ & 5 & $(12,8)$ & 3 & $\begin{array}{c}(7,9 \\
)\end{array}$ & 10 & $(25,6)$ & \\
\hline & $\begin{array}{ll}15-25 \quad \mathrm{~kg}- \\
\text { litre }\end{array}$ & 7 & (18) & 0 & 0 & 9 & $(23,1)$ & \\
\hline & Bilinmiyor & 2 & $(5,1)$ & 4 & $(10,5)$ & 6 & $(15,4)$ & \\
\hline \multirow{6}{*}{$\begin{array}{l}\text { Yumurta } \\
\text { yeme }\end{array}$} & Her gün & 1 & $(2,7)$ & 4 & $(12,5)$ & 8 & $(21,6)$ & \multirow{6}{*}{, 183 } \\
\hline & 3-5 gün/w & 12 & $(32,4)$ & 5 & $(15,6)$ & 8 & $(21,6)$ & \\
\hline & 1-2 gün/w & 15 & $(40,6)$ & 18 & $(56,3)$ & 13 & $(35,2)$ & \\
\hline & 1 gün/w & 5 & $(13,5)$ & 3 & $\stackrel{(9,4}{)}$ & 6 & $(16,2)$ & \\
\hline & 1-2 gün/m & 2 & $(5,4)$ & 2 & $(6,2$ & 2 & $(5,4)$ & \\
\hline & 1-2 gün/y & 2 & $(5,4)$ & 0 & 0 & 0 & 0 & \\
\hline \multirow{6}{*}{$\begin{array}{l}\text { Yoğurt } \\
\text { yeme }\end{array}$} & Her gün & 17 & $(44,7)$ & 16 & $(40)$ & 11 & $(29,7)$ & \multirow{6}{*}{,728 } \\
\hline & 3-5 gün/w & 15 & $(39,5)$ & 15 & $(37,5)$ & 16 & $(43,3)$ & \\
\hline & 1-2 gün/w & 4 & $(10,5)$ & 5 & $(12,5)$ & 5 & $(13,5)$ & \\
\hline & 1 gün/w & 2 & $(5,3)$ & 1 & $\begin{array}{c}(2,5 \\
)\end{array}$ & 3 & $(8,1)$ & \\
\hline & 1-2 gün/m & 0 & 0 & 3 & $\begin{array}{c}(7,5 \\
)\end{array}$ & 2 & $(5,4)$ & \\
\hline & 1-2 gün/y & 0 & 0 & 0 & 0 & 0 & 0 & \\
\hline \multirow{6}{*}{$\begin{array}{l}\text { Kuruyemiş } \\
\text { yeme }\end{array}$} & Her gün & 3 & (12) & 6 & $(18,2)$ & 4 & $(11,8)$ & \multirow{6}{*}{, 000} \\
\hline & 3-5 gün/w & 2 & (8) & 10 & $(30,3)$ & 4 & $(11,8)$ & \\
\hline & 1-2 gün/w & 5 & (20) & 6 & $(18,2)$ & 16 & $(47,1)$ & \\
\hline & 1 gün/w & 6 & (24) & 6 & $(18,2)$ & 2 & $(5,8)$ & \\
\hline & I-2 gün/m & 7 & (28) & 5 & $(15,1)$ & 8 & $(23,5)$ & \\
\hline & 1-2 gün/y & 2 & (8) & 0 & 0 & 0 & 0 & \\
\hline
\end{tabular}

P; Pearson Chi-Square testi m: ay, w: Hafta y: Yll, kg: Kilogram, gr: gram

$\mathrm{MCH}$ ve kontrol grupları yediği ekmek sayısı /gün yönünden karşılaştırıldığında istatistiki bir fark bulunmadı $(p>0,05)$. Her üç grupta çoğunlukla günde birden az ekmek tüketiyordu. Yediği ekmeğin pişirildiği yer MCH'larda \%55, kontrol-1'de \%10, kontrol-2'de \%43,6 oranında tandır fırınıydı. Tandır ekmeği yiyenlerle mide kanseri arasında istatistiksel olarak anlamlı ilişki bulunmuştur $(\mathrm{p}<0,05)$.

Et ve et ürünlerinin günlük olarak tüketimi MCH'de \%5,6, kontrol-l'de \%30,8, kontrol-2'de 
\%2,6 ( $\mathrm{p}<0,05)$ görüldü. Tütsülenmiş et ürünleri yeme, sucuk, pastırma ve sosis yeme yönünden her üç grup karşılaştırıldığında istatistiki bir fark bulunmadı( $p>0,05)$. Tuzlanıp-saklanmıș et ürünleri tüketme günlük, haftalık, aylık ve yıllık olarak hesaplandı; $\mathrm{MCH}$ grubunda günlük $\% 5,6$, kontrol-1 grubunda \%25, kontrol-2 grubunda $\% 4,7$ bulundu $(\mathrm{p}<0,05)$. Tuzlu peynir yeme günlük olarak hesaplandığında $\mathrm{MCH}$ grubunda $\% 35,3$, kontrol-1 grubunda \%74,3, kontrol-2 grubunda \%72,7 $(\mathrm{p}<0,05)$ bulundu.

Çay içme yönünden her üç grup arasında istatistik bir fark bulunmadı ( $p>0,05$ ). Kırmızı pul biberi tüketimi günlük olarak hesaplandığında MCH'larda günlük \%24, kontrol-1'de günlük $\% 46,9$, kontrol-2'de günlük $\% 46,7$ ( $\mathrm{p}<0,05)$ saptandl.

Meyve yeme günlük ve haftalık olarak hesaplandığında $\mathrm{MCH}^{\prime}$ larda haftalık \%37,2, kontrol-1'de \%51,3 (p<0,05), kontrol-2'de haftalık \%35,9 saptandı. Sebze tüketme açısından her üç grup karşılaştırıldığında gruplar arasında istatistik bir fark bulunmadı ( $p>0,05)$.

Ailenin aylık yă tüketimi MCH'ların $\% 33,3$ 'ünde $5 \mathrm{~kg}$ veya litreden az, kontrol-1'in $\% 68,4$ 'ünde $(\mathrm{p}<0,05) 5 \mathrm{~kg}$ veya litreden $\mathrm{az}$, kontrol-2'in \% 15,4'inda $5 \mathrm{~kg}$ veya litreden az olduğu tespit edildi.

\section{TARTIŞMA}

Mide karsinomunun belirli bölgelerde ve belirli toplumlarda anlamlı olarak daha sık olması etyopatogenezinde çevresel faktörlerin araştırılmasına yol açmıştır. Ancak, çeşitli çalışmalarda farklı sonuçların elde edilmesi, araștırmacıları belirli bir besin türünün etkisinden çok besinleri saklama ve pişirme alışkanlıklarındaki farklılıklara ve besinlerdeki koruyucu faktörlerin etkilerine yönlendirmiştir ${ }^{1}$.

Çalışmaya katılan MCH'ların genel özellikleri;
- İleri yaş, erkek cinsiyet, A kan grubu

- Sebze-meyveden kısıtlı beslenme

- Kırsal kesimde yaşama, ekmeğini tandır fırınında pişirme, et ve et ürünleri az tüketme

- Kalabalık aile ortaminda yaşama

- Eğitim düzeyleri düşük, aylık gelir düzeyleri normal şartların altında

- Ağız bakımı ve diş fırçalama alışkanlıkları yetersizliği

- Tanı aldıklarında mide kanseri ileri evrede

- Çiftçilik ve ev hanımı mesleği baskınlığı

- İlk başvurusunda çoğunda anemi saptanması

Erkeklerde demir eksikliği anemisi, kadınlarda ve erkeklerde gaitada gizli kan varlığı gizli bir gastrointestinal lezyon açısından araştırmayı zorunlu kılar8. Yukarıdaki özellikleri bir bütün olarak değerlendirildiğinde, hepsinin altında sosyoekonomik ve sosyokültürel düzey düşüklüğü yattığı düşünülebilir. Kalabalık yaşam, kırsal yaşam, toprakla temas halindeki çiftçilik mesleği, içme (kuyu, çeşme) suları mide kanserinde etiyolojik olarak suçlanan ${ }^{9,11}$ helikobakter pylori prevalansını artırmaktadır. İçme suyu ile MCH ilişkisini saptamadik. Gastrik kanser riski sosyoekonomik düzeyi düşük sınıfın içinde en fazladır8. Toprak ve içme sularındaki yüksek nitrat konsantrasyonu gastrik kanserden ölüm hızı fazla olan alanlarda gözlenmiștir ${ }^{12}$. Türkdoğan ve arkadaşları 2003 yılında Van yöresinde yapmış oldukları çalışmada oduntezek ateşinde (tandır fırını) pişen ekmekte ve içme suyu örneklerinde nitrat ve nitrit düzeyleri ileri derecede anlamlı olarak yüksek bulmuşlardır ${ }^{13}$.

Demirer ve arkadaşlarının yapmış olduğu bir çalışmada diş fırçalama alışkanlığının MCH'larda pek olmadığı vurgulanmıştır ${ }^{14}$. Yüksek kanser riski olanlar; ailede mide kanseri varlı̆̆ı, A kan grubu, erkek cinsiyet, 
ileri yaș, tütsülenmiș tuzlu yiyecek ve düşük miktarda C vitamini tüketme, yüksek lahana diyeti, aklorhidri, düşük sosyoekonomik düzey, düşük miktarda A vitamini alımı, sigara ve alkolü alışkanlık edinme sayılabilir9,10.

Gastrik karsinogenesiste sigara dumanında bulunan nitrözaminler ve diğer nitröz bileşikler suçlanmış ${ }^{15}$. Gastrik kanser riski üzerinde alkol etkileri için bir kaç epidemiyolojik kanıt vardır ${ }^{16}$. Bir Japon kohort çalışması gastrik kanserle pozitif bir ilişski göstermesine rağmen, çoğu böyle çalışmalar hiçbir ilişki gösterememişlerdir ${ }^{17-19}$. Bizim çalışmamızda $\mathrm{MCH}$ ve alkol-sigara ilișkisi saptamadik.

Çalışmamamızda her üç grupta evde buzdolabı bulunma eşitti. Muhtemelen çalışmayı yürüttügümüz bölgede yaz mevsiminin çok sıcak geçmesinden dolayı herkes buzdolabı alma zorunluluğu hissetmektedir. Buzdolabı kullanımı dolaylı olarak (saklanmış gıdanın alımını azaltır ve taze meyve-sebze tüketimini artırır) mide kanserin riskini düşürmeye yol açabildiği varsayılmaktadır ${ }^{20,21}$, ancak buzdolabının ne miktarda bu amaç için kullanıldığı bilinmemektedir. Belki de suyu daha çok soğutmak için kullanılmaktadır. MCH'larımı sebze ve meyveden kisitlı besleniyordu. Demirer ve arkadaşları 1990'da iç Anadolu bölgesinde yaptıkları bir vakakontrollü çalışmada MCH'larda buzdolabı kullanımının daha az olduğunu bulmuşlardır ${ }^{14}$.

Tütsülenmiș etler, sucuk, pastırma, sosis, tuzlu peynir, turşu, tuzlanmış salamuralı zeytin, etet ürünleri, tandır firınında pişmiş beyaz ekmek, kırmızı pul biberi, kuruyemiş gibi değişkenlerin başlığı altında nitrözasyonu ve tuzu değerlendirmek gerekir. Nitrözasyona ve tuza başlamadan şunu vurgulamakta fayda var, çalışmamızda demin söz ettiğim değişkenlerin çoğu anlamlı bulunmadı. Bunu çalışmamızdaki $\mathrm{MCH}$ sayımızın yetersizliğine bağlanabiliriz. Kanserli hastalarımızın çoğunun sosyokültürel düzeyi düşük ve genel durumu düşkün olduğu için belki de anketi yeterince anlayamadılar. Anlamlı çıkan değişken; yedikleri ekmeğin tandır fırınında pişiyor olmasıdır. $\mathrm{Bu}$, gıdalardaki nitratın yüksek konsantrasyonun uzun süreli sindirimi yüksek mide kanser riskiyle ilişkili olduğu görülmektedir. Bakteriler nitratı karsinojenik nitrite dönüştürdüğü düşünülüyor. Böyle bakteriler kısmen bekletilmiş gıdaların sindirimi yoluyla alınabilir. Dünyada sosyoekonomik düzeyi düșük sınıflarda bu bakteriler gidalarla bolca alınır. Helikobakter pilori gibi bakterilerin midede bakteriyel artışı, gastrik asiditenin azalması, kronik gastrite neden olarak nitratı nitrite dönüştürür8. Mevcut çalışmada, sıklıkla soya sosuyla tuzlu baharat kullanılan turşu ve balık (çiğ, kaynatılmış, kızartılmış balık) gibi tuzlanmış gıdalar gastrik kanserle hiçbir ilişkinin güçlü kanıtı bulunmadı. Yüksek ısıda pişirilmiş ve uzun bir süre için heterosiklik aminler içeren hayvansal besinler hayvansal karsinojenler ve mutajenlerdir ${ }^{16}$.

Tatlı, beyaz ekmek, çaya katılan şeker miktarı, çiğ etten yapılmış yiyecekler gibi değişkenler nişasta başlı̆̆ altında incelenebilir. Nişasta literatürde mide tahribatını en az tuz kadar yapmaktadır. Çalışmamızda bu değişkenlerle anlamlı bir sonuç çıkmadı. Muhtemel sebep, çalıșmayı yürüttüğümüz bölgede insanların büyük bir kısmı sofralarında beyaz ekmek, unlu tatlılar, aperatif olarak çiğ köfte bulundurmalarıdır. Ek olarak aynı bölgede yaşayan insanlarının tümü șekeri tüketmekten hoşlanırlar. Buiatti ve arkadaşlarına ${ }^{7}$ göre nişasta ürünleri tekrar ısındıktan (bakteriyel içerikte yeterli düşüş yokluğunda) sonra sıklıkla tüketilmektedir. Nişastalı gıdalar düşük protein diyetiyle ilişkili olabiliyor ${ }^{22}$. Sonuçta, yüksek nişastalı diyetler gastrik mukozada fiziksel iritasyon, gastrik musinde düşme, gastrik pH'nın düşmesi sonucunda 
mekanik olarak hasarla sonuçlanabilìr22,23. Özellikle kompleks tahıllardan elde edilen proteinlerin yüksek seviyede, diyette hayvansal yağ ve proteinlerin düşük düzeyde olması, lifli ve taze yeşil bitkilerin seyrek yenilmesi, tuz ve nitratın fazla tüketilmesi mide karsinom gelişimini kolaylaştıran etmenler olarak öngörülmüştür1 ${ }^{1}$. Literatürle uyumlu olarak çalışmamıza katılan MCH'ları az et (protein) tüketiyorlardı.

Taze, yeşil-sarı sebzeler ve süt mide kanseri gelişimine karşı koruyucu faktörlerdir6. Çalışmamızda meyve suyu, sebze, yoğurt, yumurta ve süt MCH ilişkisizken, salata ve meyve ise $\mathrm{MCH}$ ile ilişsili bulundu. Çalı̧̧ma yürüttüğ̈müz bölgede hayvansal yağ, süt ürünleri, yumurta, işkembe, hayvan iç organların kavurması ve tütsülenmesi insanların ana besin kaynağıdır. Bunun üzerine katkı olarak tuzu düşünebilirsiniz. Sosyoekonomik düzey ve kültür nedeniyle sebze ve meyve ya bulamıyor ya da alışkanlık haline getirmemiştir. Ayrıca bu gıda grupları, diğer besleyici ve biyoaktif maddeler arasında, askorbik asit, B-karoten ve diğer karotenoidlerden zengindir. Gerçekten vitamin C intragastrik nitrözasyonu bloke eder, böylece gastrik karsinogenezisde, atrofik gastrit, displazi, karsinoma gelişim basamaklarına doğru aşamayı engeller ${ }^{24}$. Total sebze ve meyve alımı üzerindeki kohort çalışmalarında tespit edilen kanıt, bir metaanaliz yaklaşımda anlamlı protektif etki gösterilmemiş ${ }^{25}$.

Çalışmamıza katılan bireylerde her üç grupta eşit bir şekilde çay içilmekteydi. Kahve MCH grubunda az tüketilmektedir. Çalışmayı yürüttügümüz alanda yaşayan halkın ana içecek kaynağı sudan sonra çaydır. Kahve tüketimi daha azdır. İsveç'te vaka-kontrollü bir çalışmada siyah çay alımının gastrik kanser riskinde önemli düşüşle ilișkili olduğu gösterilmiştir ${ }^{26}$. Kahve tüketimi erkeklerde mide kanserinin riskiyle ilişkisinde önemli zıtlık gösterilmiştir. Batı tarzı kahvaltısı olan erkekler mide kanserin önemli düşük riskine sahiptir. Kahve tüketimi batı diyet alışkanlı̆̆ şeklinde düşünülmesi gerekir. İnsanlarda normal miktarlarda tüketildiği zaman ${ }^{19}$ kahve karsinojenik olacağı düşünülmemesine rağmen, mutajenik maddeler kahvede 27-29 bulunmuştur. Gastrik karsinogenesiste kahve ve çayın rolü üzerinde daha fazla çalışmalara ihtiyaç vardır.

Kullanılan yağ türü miktarına gelince; Katı margarin kullanımı ve aylık yağ tüketimi MCH'larımızda fazla bulundu. Katı margarin en ucuz yağdır, çalışmayı yürüttüğümüz sahada genelde bu yağ kullanılmaktadır. Kavurma ve tava had safhada tüketilmektedir. Bu nedenle aylık yağ tüketimi oldukça fazladır. Az yağ alımı daha dengeli bir diyetle seyrettiği için koruyucu etkili olabilir8. Protein, sature yağ, kolesterol ve sodyumun fazla tüketimi gastrik kanser riskini artırır. Oysa poliansature yağ, vitamin A-C tüketimi gastrik kansere protektif etkiye sahip olabilir ${ }^{30}$. Et ve et ürünlerinin tüketimi $\mathrm{MCH}$ ile ilişkisi saptanmadı. Rafine edilmiş şeker ve yağdan zengin beslenme gastrik kanserle sürekli iliş̧isizdir ${ }^{31}$.

\section{SONUÇ}

Mevcut çalışmada mide kanseri ile besin grupları arasındaki ilişkileri analiz edildi. Bazı besin maddeleri $\mathrm{MCH}$ ile ilişkiliyken, bazıları ilişkisizdi. İleri yaş, erkek cinsiyet, kırsal yaşam, ev hanımı ve çiftçilik mesleklerini icra etme, sosyokültürel-sosyoekonomik düzey düşüklüğü, kalabalık ailede yaşam, A kan grubu, sebze-meyveden kısıtlı beslenme, kötü ağız hijyeni ve diş firçalama alışkanlığının yetersizliği MCH'larında anlamlı bulunan değişsenlerdi. MCH'ları et, tuzlanıp-saklanmış et ürünleri, tuzlu peynir, tuzlanmıș salamura zeytin, kahve, kırmızı pul biberi, meyve, salata, kuruyemiş gibi besin ve içecek gruplarını az tükettikleri tespit edildi. MCH'ları tandır firın 
(atește/közde pișmiș) ekmeği ve katı-sıvı yağ tüketimi oldukça anlamlıydı. Mide kanseri ile beslenme arasındaki ilişkiyi aydınlatmak için daha kapsamlı ve kontrollü çalışmalara ihtiyaç duyulmaktadır.

Etik Kurul Kararı: Tüm katılımcılardan bilgilendirilmiș onam alındı. Bu çalıșma, etik kurul izni (Tarih:21.10.2019, Sayı:215) ile Helsinki Beyanı'na uygun olarak yapılmıștır.

Çıkar Çatışması Beyanı: Yazarlar çıkar çatışması olmadığını bildirmişlerdir.

Finansal Destek: Bu çalışma her hangi bir fon tarafından desteklenmemiștir.

Declaration of Conflicting Interests: The authors declare that they have no conflict of interest.

Financial Disclosure: No financial support was received.

\section{KAYNAKLAR}

1. Correa, P. The epidemiology of gastric cancer. World J. Surg. 15, 1991: 228-34. https://doi.org/10.1007/BF01659057

2. Karaoğuz H, İçli F. Cancer problem in Türkiye. J Ankara Med School 1993; 15: 547-58.

3. Reiter W, Stieber P, Reuter C et al. Prognostic value of preoperative serum levels of CEA, CA 19-9, CA 72-4 in gastric carcinoma. Anticancer Res 1997; 17: 2903-6.

4. Sugimura T, Wakabayashi K. Gastric carcinogenesis: diet as a causative factor. Med Oncol Tumor Pharmacother. 1990; 7: 87-92.

5. Howard W, Bruckner MD, John C, et al. Neoplasm of the stomach Cancer. Medicine, 2002; 7: 1355-90.

6. Tominaga S. Cancer incidence in Japanese in Japan, Hawaii, and Western United States. NCI Monogr 1985; 69: 83-92.
7. Buiatti E, Palli D, Decarli A, et al. A casecontrol study of gastric cancer and diet in Italy. Int J Cancer 1989; 44: 611-6.

8. J. Larry Jameson, Dan L. Longo, Stephen L. Hauser, Anthony S. Fauci, Eugene Braunwald, Dennis L. Kasper. Harrıson's principles of internal (Boșluk giderildi)medicine 15 th edition. Volum 1 sayfa 580

9. Akdoğan RA ve ark. Mide Tümörleri, Gastroenteroloji, Türk Gastroenteroloji Vakfi, 2002: 107-12.

10. Graziano F, Humar B, Guilford P. The role of the E-cadherin gene (CDH1) in diffuse gastric cancer susceptibility: from the laboratory to clinical practice. Ann Oncol 2003; 14: 1705-13.

11. Antonioli DA. Precursors of gastric carcinoma: a critical review with a brief description of early (curable) gastric cancer. Hum Pathol. 1994; 25: 994-1005.

12. Goldman ausiello. cecil textbook of medicine 22th edition sayfa: 1208.

13. Türkdoğan MK, Testereci H, Akman N, et al. Dietary nitrate and nitrite levels in an endemic upper gastrointestinal (esophageal and gastric) cancer region of Turkey. Turk J Gastroenterol. 2003; 14: 50-3.

14. Demirer T, Icli F, Uzunalimoglu O, et al. Diet and stomach cancer incidence. A case-control study in Turkey. Cancer. 1990; 65: 2344-8.

15. Jedrychowski W, Wahrendorf J, Popiela T, et al. A case-control study of dietary factors and stomach cancer risk in Poland. Int J Cancer 1986; 37: 837-42.

16. Corella D, Guillén M. Dietary habits and epidemiology of gastric carcinoma. Hepatogastroenterology 2001; 48: 1537-43.

17. Glade MJ. Food, nutrition, and the prevention of cancer: a global perspective. American Institute for Cancer Research/World Cancer Research Fund, American Institute for 
Cancer Research, 1997. Nutrition. 1999; 15: 523-6.

18. Kato I, Tominaga S, Ito Y, et al. A prospective study of atrophic gastritis and stomach cancer risk. Jpn J Cancer Res 1992; 83: 1137-42.

19. Inoue $M$, Tajima $K$, Hirose $K$, et al. Life-style and subsite of gastric cancer-joint effect of smoking and drinking habits. Int J Cancer 1994; 56: 494-9.

20. Coggon D, Baker DJ, Cole RB, et al. Stomach cancer and food storage. JNCI 1989; 81: 11781182.

21. La Vecchia C, Negri E, D’Avanzo B, et al. Electric refrigerator use and gastric cancer risk. Br J Cancer 1990; 62: 136-7.

22. Kono S, Hirohata T. Nutrition and stomach cancer. Cancer Causes Control 1996; 7: 41-55.

23. Munoz N, Plummer M, Vivas J, et al. A casecontrol study of gastric cancer in Venezuela. Int J Cancer 2001; 93: 417-23.

24. Correa P. Human gastric carcinogenesis: a multistep and multifactorial process. First American Cancer Society Award Lecture on Cancer Epidemiology and Prevention. Cancer Res 1992; 52: 6735-40.
25. Fukunaga M, Monden T, Nakanishi $H$, et al. Immunohistochemical study of p53 in gastric carcinoma. Am J ClinPathol 1994; 101: 177-180.

26. Hansson LE, Nyrén O, Bergström R, et al. Diet and risk of gastric cancer. A population-based case-control study in Sweden. Int J Cancer 1993; 55: 81-9.

27. Nagao M, Takahashi Y, Yamanaka H, et al. Mutagens in coffee and tea. Mutat Res 1979; 68: 101-6.

28. Sugimura T, Sato S. Mutagens-carcinogens in foods. Cancer Res 1983; 43: 2415-21.

29. Timson J. Caffeine. Mutat Res 1977; 47: 1-52.

30. Jiong-Liang Qiu, Kun Chen, Jian-Ning Zheng, et al. Nutritional factors and gastric cancer in Zhoushan Islands, China PO Box 2345, Beijing 100023. China World J Gastroenterol 2005; 11 : 4311-6.

31. Palli D, Russo A, Decarli A. Dietary patterns, nutrient intake and gastric cancer in a high-risk area of Italy. Cancer Causes Control. 2001; 12: 163-72. 